Sign Systems Studies 49(3/4), 2021, 383-399

\title{
Marlen Haushofer's The Wall and the post-nuclear culture of the face
}

\author{
Emanuela Ferragamo'
}

\begin{abstract}
The intertwining of landscape and face belongs to human spatial epistemology: as suggested by Matteo Meschiari, primitive humans used to orientate themselves in landscape through recognition of facial patterns. By reflecting upon Marlen Haushofer's novel The Wall (Die Wand), the article aims to question the semantic of the "face of the landscape" in the wake of an imagined nuclear apocalypse that leaves behind a cat, a cow, a dog, a woman and a wall. The wall transcends the boundaries between human and other-than-human: in terms of Roberto Marchesini, it creates a somato-landscape - a hybridization of inner and outer landscapes typical of post-human awareness. Finally, such a landscape culminates in the dismissal of the pre-apocalyptic culture of the face: faces no longer function as a means of recognition.
\end{abstract}

Keywords: face; landscape; boundary; exotopy; hyperobject; melancholy; trouble

\section{Introduction}

The Austrian writer Marlen Haushofer published the novel The Wall (Die Wand) in $1963 .^{2}$ The novel begins rather simply: the protagonist, a middle-aged widow, goes to the Austrian mountains to spend some time with her cousin Luisa and Luisa's husband Hugo. However, on the day after her arrival she finds herself alone in the house. When looking for her hosts, who have not returned, she discovers a transparent wall at the end of the mountain's gorge.

Manuscripts show that Haushofer gave the novel its present title, thematizing one of her recurrent metaphors (Schmidjell 2000: 47). Indeed, critics interpret the 'wall'

1 Foreign Language, Literature and Cultures Department, University of Turin (Unito), Via Verdi 8 - 10124 Turin, Italy; e-mail: emanuela.ferragamo@unito.it.

2 I quote from the edition published by Ullstein Taschenbuch (Haushofer 1985) and refer to the novel through its initials followed by the page numbers, and provide the English translation by Shaun Whiteside (Haushofer 1999) in the footnotes. I refer to the latter through its initials followed by the page numbers. 
in the context of her repeated reference to constricted places (Von der Lühe 1986: 82), where she staged both women's oppression and a possible exit from patriarchy. ${ }^{3}$

More recently, literary inquiries have re-established an interest in the narrative of natural space and landscape in The Wall. ${ }^{4}$ The present paper stems from this context and studies how the post-nuclear landscape of the novel affects the depiction of faces in it, analysing the relationship between the terms 'landscape' and 'face', while referring to Umberto Eco's (1985: 10) concept of semiotics as a process of integrating one's reflection as the symbolic image of the Self in a broader, symbolic system.

The paper consists of three parts. Firstly, the narrative function of mirrors is highlighted with reference to the status of the presence of the face in a post-nuclear word where the protagonist is the only survivor. Reflecting on mirrors means considering the problem of recollection of the past in the symbolic constitution of the protagonist's face in her silent dialogue with the dead.

3 Regula Venske views the novel as an expression of Haushofer's tendency to stage the quest for identity in non-places where women's boredom is both the expression and the consequence of the psychological suffering of women in middle-class society (Venske 1987: 199). However, those places of sensorial inexistence express not only a desire for self-annihilation, but also a struggle to overcome the stifling social conventions of post-war Austria (Venske 1987: 205). In The Wall, Haushofer's last woman fights for survival, thus introducing an intertextual reference to Robinson Crusoe. However, more recent criticism tends to question the connection: Michael Hoffman (2000: 202) underlines the characters' different approaches to natural resources and a more problematic use of the utopian genre in Haushofer's novel. The question of a gendered genre is also relevant: Sarah Nelseen (2019: 136) suggests reading Haushofer's robinsonade through Donna Haraway's' concept of SF as both Science Fiction and Speculative Feminism.

Some critics view the killing of the last man at the end of the novel in the light of an urge to masculinize women: the murder of the last surviving man appears as an allegory of women's emancipation from all sorts of masculine projections. However, the murder has negatively influenced the reception of her novel. Thus, it comes as no surprise that feminism has been just recently discovering Haushofer's legacy, reconquering a long-neglected author (Knecht 2007: 84). During the 1970s, feminists greeted the last pages of her novel with a certain puzzlement due to a resistant inhibition towards feminine aggression (Venske 1987:213) and the predominance of elements of fragility and sensibility in women's representations (Venske 1991: 23).

4 Here, I quote Régine Battiston's recent essay on the meaning of landscape in Haushofer's work (Battiston 2019) and Johanna Chlovanec's and Grazziella Predoiu's (2016) articles on her semiotics of space. The latter draw on Eduard Soja's postmodern concept of 'thirdspace' and on a reinterpretation of the robinsonade through a psychological analysis of the plot, respectively. According to Chlovanec (2006: 26-28), Soja's thirdspace reveals a third path in the narrative of gender that goes beyond the dichotomy male versus female and deconstructs the patriarchal assumption as such. Predoiu (2016: 76-77) focuses on the idyllic scenery and views the wall as an allegory of the desire of a symbiosis with nature. 
Secondly, such a dialogue takes place within boundaries. Not only is the wall a hindrance, but it also originates a semiosphere and results in the ultimate construction of a palisade beside its surface. By doing this, the protagonist reinterprets her previous epistemology in a sense that transects gender and physical boundaries: the wall and the palisade trigger an exotopic process of transection between the inside and the outside of the semiotic system. This aspect is analysed through the post-human idea of somato-landscape (Marchesini 2002: 189).

Finally, Haushofer's landscape is observed from the theoretical perspective of hyperobjects. In this view, the smooth surface of the wall appears as an anticipation of the smooth space of Gilles Deleuze's and Felix Guattari's theory of space.

\section{The face and the other: The face as a means of recollecting the past and the quest for one's identity in Haushofer's novel}

\subsection{Facing landscape}

Landscape means different things to different disciplines, its currency not always a guarantee for taxonomic clarity. ${ }^{5}$ In this paper, I will follow Matteo Meschiari's suggestion and study Haushofer's landscape in profile, which means discussing its textual practice, rather than its essence (Meschiari 2008: 276). In order to do so, I refer to Paolo D'Angelo (1999: 210-211) who summarizes the term's definitions as involving the typical form of a territory: a portion of earthly surface that constitutes an image or, more generally, perceptive data received by an observer. This definition helps us to outline an operative definition of landscape emerging in Haushofer's novel.

While studying the aesthetic meaning of the subject's response to landscape, D'Angelo questions its relationship with a philosophical view of nature, which would possibly go beyond the ecological underappreciation of aesthetics. Thematizing beauty as the crux of modernity, D'Angelo (2001:110) aims to examine its connection with the historical and imaginative context of of the observer's culture.

Haushofer depicts landscape as a cultural image originating from the collective intervention on a territory.

Firstly, the emergence of the wall destroys the idyllic scenery of the Alps, as the protagonist no longer finds the mountain "romantic and charming" but "damp and gloomy" (TW: 19). As in the aftermath of the Second World War Austrian political discourse would shape national identity thanks to the Alpine landscape, thus

5 For a useful and clear taxonomy of 'landscape' see Berque 1994, Schama 1995, Jakob 2005, Weber 2010 and Sobral Campos 2019. 
distancing itself from Nazi Germany (Zeyringer 2001: 60), the appearance of the wall thematizes the struggle to deal with the collective memory of the Holocaust as it forces the protagonist to cope with the "inability to mourn" of her generation (Knecht 2007: 83). The protagonist finally understands how to deal with the wall by letting her emotions out, bursting into tears while recollecting the dead on Christmas Eve.

Secondly, the wall relates to the Cold War psychosis of nuclear destruction. As the wall represents the collective fault of an entire age, it has no inventor and is a step towards the ongoing alienation of modern humanity. More generally, the wall marks the abrupt end of the ancient, intimate relationship between man and nature. In this respect, its naissance recalls in some sense what Michael Jakob considers the origin of landscape: the loss of the antique harmony of cosmos (Jakob 2005: 15).

D'Angelo emphasizes the process of shaping the territory in the making of landscape, thus implicitly recalling the history of the term: Germanic and Romance languages form the word 'landscape' using a suffix that indicates a territory and its configuration: '-age' in French, '-scape' or '-schiftz' in old English (Collot 2005: 152). Furthermore, they intend landscape as a way of organizing data in a coherent unity that is to be realized both in arte and in visu (Collot 2005: 156). As Timothy Morton has argued, landscape embodies a subjective state: a landscape picture "is less about land, then, and more about scape. We talk about the mood of a landscape, the feeling it evokes in us" (Morton 2011: 80).

The landscape's position in front of the observer is particularly evident in Haushofer's novel. Here, the protagonist literally bumps her forehead against the wall: a sort of transparent screen through which landscape appears as a distant image (DW: 14).

The fact that landscape is in front of the subject guarantees its visibility in the first pages of the novel, the latter implying historically the possibility of controlling information and resources. The organization of landscape expresses political longing for controlling the territory (Vitta 2005: 148). In this respect, it is relevant that Haushofer highlights a connection between the transparency of the wall and the desire of the protagonist to keep everything under visual control (DW: 187). However, the novel problematizes the idea of landscape's full visibility. While in the 18th-century utopian fiction transparency is positive (Baczko 1978: 22), the one of the wall forces the protagonist to walk with outstretched arms in order not to get hurt (DW: 15). 


\subsection{Facing faces}

Haushofer's critique of the paradigm of visibility also affects the perception of faces. The German word 'Gesicht', that appears in the German-language version of Haushofer's novel, has its roots in the verb 'sehen', designating the outer, visible dimension of face. ${ }^{6}$ In the novel faces seem hard to catch, even in places where they should be present. The protagonist's reflection in Luise's vanity mirror speaks more of the missing woman than of the present one: "In Luises Frisierspiegel sah ich manchmal verwundert meine neue Erscheinung. Mein Haar, das stark gewachsen war, hatte ich mit der Nagelschere kurz geschnitten. Es war jetzt ganz glatt und von der Sonne gebleicht. Mein Gesicht war mager und gebräunt" (DW: 81-82). ${ }^{7}$

Appearing in the mirror, the protagonist recalls the disappearing of the person to whom the object once belonged: Luise, who died after the appearance of the wall. The protagonist imagines her as a doll with red lips and reddish-blond curls (DW: 124). The depiction of Luise as a sleeping beauty clearly expresses Haushofer's criticism of patriarchy (Chamayou-Kuhn 2019: 30) and the emotive stiffness caused by women's efforts to fit a stereotypical image: Luise seems in a desperate need of social acceptance (DW: 12). ${ }^{8}$

When reflecting upon the appearing and disappearing of the protagonist and Luise in the mirror, we may recall Eco's (1985: 18) dismissal of mirrors as semiotic channels. Mirrors put a sender and an addressee in contact, but they do not generate a semiosis: this would require the absence of the object for whom the sign stands, while mirrors need the object referred to be present (Eco 1985: 19). Yet the mirrored object appears to be strangely present in the passage quoted above. In a way, Luise appears in the mirror in the sense that the protagonist is forced to remember her face (DW: 82). Thus it seems that Haushofer thematizes presence as the effect of recollection, giving transparency a rather melancholic quality.

Hidden objects fascinate us because they seem to suggest that something has become lost: facing a veiled face, we are in front of an enigma (Starobinski 1957: 7). Seduced by the object without being satisfied, our eyes keep trying to catch a glimpse of the reluctant promise of appearance (Starobinski 1957: 7). The wall causes a similar dynamic. The protagonist is afraid of looking through the wall

6 See http://woerterbuchnetz.de/cgi-bin/WBNetz/wbgui_py?sigle=DWB\&mode=Vernetzung\& lemid=GG11297\#XGG11297.

7 "I sometimes looked with amazement at my new appearance in Luise's dressing-table mirror. As my hair had grown a great deal, I had cut it short with the nail-scissors. Now it was quite flat, and bleached by the sun. My face was thin and tanned, [...]" (TW: 68).

8 Considering Luise's need to be liked, it is interesting that the mirror represents a relevant tool for feminist studies to destructure social representations of women (Stephan, Weigel 1988). 
and of seeing anything more than what she has understood in her heart of hearts (DW: 12). Therefore, as she reaches the top of a raspberry patch and observes the landscape through her binoculars from there, she does not manage to discern the face of a motionless woman sitting in front of the coachmaker's cottage beyond the wall (DW: 29). Her attempts at focusing on the face of the unknown woman are in vain: in the end, images fade in a kaleidoscope of forms and colours (DW: 29).

Starobinski (1975: 8) understands such frustration as melancholy: the fact that the desired object is in full sight and yet impossible to reach. This can be related to Massimo Leone's (2015: 126) reflection upon the semiotics of transparency: when Leone suggests considering transparency as an anticipation of transcendence, he means that transparent objects are destining actants - they prevent the sight as obstacles and at the same time they arouse the desire to see.

The apprehension towards hidden faces beyond the wall could also be interpreted as the result of two distinctive moments which characterize recollection: availability and accessibility. Paul Ricoeur (2004: 129) believes that Henri Bergson had the merit of solving a long-lasting riddle of memory: the fact that its images are simultaneously lost, yet available through recollection. Still, the clue to this apparent paradox relies on the centrality of recognition: to let recollection exist, the subject has to recognize it as something with its roots both in the past and in the present (Ricoeur 2004: 142). Therefore, recognizing the past means recovering it, and recovering it means presuming it to be available, if not accessible (Ricoeur 2004: 143).

The same dilemma occurs in a passage in Haushofer's novel in which she imagines her protagonist trying to reach some pansies, while, unfortunately, the flowers grow on the other side of the wall: "Einmal im Frühling [...] sah ich drei oder vier Veilchen. Gedankenlos streckte ich die Hand aus und stieß in die Wand. [...]. Die Veilchen hielten mir ihre kleinen violetten Gesichter entgegen, aber ich konnte sie nicht anfassen" (DW: 167). ${ }^{9}$ Seeing the pansies, she mistakes their visual accessibility for their actual availability, yet the mistake is soon corrected: the flowers' perfume she thought she smelled when she first glanced at the flowers dissolves after she has touched the wall (DW: 167).

9 "Once in the spring [...] I saw three or four violets. I absently reached out my hand and leaned against the wall. [...] The violets held their little purple faces to me, but I couldn't not touch them" (TW: 145). 


\subsection{From the other side of the mirror.}

By letting her protagonist stand in front of a mirror, Haushofer explores the relationship between present images and their recollection. In doing so, she reflects upon the semiotics of the mirror: the object for whom the sign in the mirror stands coincides only partially with the actual object.

On another occasion, Haushofer addresses the topic of mirroring again, depicting the protagonist's face as a reflection in her cat's eyes. "Ich sehe mein Gesicht, klein und verzerrt, im Spiegel ihrer großen Augen", she writes (DW: 52). ${ }^{10}$ While the previous quote emphasized the protagonist's estrangement from her appearance in Luise's mirror, here Haushofer underlines the fact that her face has lost its original proportions: it has become small and distorted. In a general sense, this disproportion speaks for the asymmetry between the Self and the other, which characterizes the ethical philosophy: giving a prominent status to the other, its premises stem from asymmetry, rather than reciprocity (Ricoeur 2004: 181). In other words, if we act ethically, we give more importance to the other than to ourselves. This is why the protagonist depicts herself as small in comparison to the cat: being the last human on earth, the protagonist feels how the responsibility towards her animals and the wild is hers only to bear (DW: 127).

Moreover, the disproportion between the "smallness" of the protagonist's face and the size of her cat's eyes can be interpreted as a plea to her counterpart to accept the moral quest for relationship conveyed through visual contact. Emmanuel Levinas understands the presence of faces as a moral awakening: they express the eternal transcendence of the other, metaphorically breaking through the world (Lévinas 1977: 199).

On the one hand, Haushofer imagines the relationship between the protagonist and the cat like motherhood: the protagonist first notices the starving cat after she thinks she has heard a baby crying (DW: 48) and, slowly, she becomes dependent on the animal (DW: 51). On the other hand, as an independent, cautious animal, the cat can be seen as representing the irreducible extraneousness of the other in Mikhail Bakhtin's terms. Relating with the other means for him overcoming monologism on the linguistic level, responsibility and care on the moral level, and exotopy on the aesthetic level (Ponzio 2003: 189-190). In Bakhtin's works, exotopy results from a reconsideration of the terms "inside vs. outside and defines a transitioning of those two dimensions into one another: a process that is not dialectic but represents a conceptualisation of the outside as traversing between two discourses" (Kalinova 2018: 105).

10 "I can see my face, small and tight, in the mirror of her big eyes" (TW: 41). 
Exotopy comes into mind when we consider the fact that the cat wears a typographic sign on its fur: "Die Katze starrt aus gelben Augen in die Ferne. Manchmal kommt sie plötzlich zu mir zurück, und ihre Augen zwingen mich, die Hand auszustrecken und den runden Kopf mit dem schwarzen M auf die Stirn zu streicheln" (DW: 149). ${ }^{11}$ Where someone else might have seen nothing but the pattern of a cat's coat, the protagonist sees a letter and not just a random one - ' $M$ ' being the initial of Haushofer's first name, Marlen. As Augusto Ponzio (2003: 57) notices, exotopy means the invisibility of the objective author, emerging because of literary criticism, and of the objectivized one, representing the author in his or her work. Therefore, authorship appears as a pure representational principle: defying representation, the author is present in the dialogue of his or her many voices (Ponzio 2003: 58).

Referring to the peculiar invisibility of the author and paraphrasing Levinas' formulation for the ethical relationship with otherness, the silent dialogue between the cat and the protagonist breaks through monologic writing, renegotiating the boundaries between the inner and the outer.

\section{Surviving beyond the wall: The wall as a boundary}

\subsection{The wall is more than just a wall}

In Haushofer's novel, this renegotiation takes place in an era of hyperobjects. In the philosophy of Morton, hyperobjects designate both the object of study and its theoretical frame. The premise of Morton's thinking lies in the confutation of Kant's epistemology and his idea of a distance between the observing subject and the observed object (Morton 2013: 27). In this regard, Morton (2013: 27) considers global warming as a typical example of a hyperobject outside of which it is impossible for us to step.

Although hyperobjects suit postmodern literature better, they appear to be useful tools to interpret Haushofer, since they permit underlining of two aspects of her depiction of the landscape and have a meaningful role in the understanding of faces.

Firstly, both the wall of Haushofer's novel and hyperobjects result from an apocalypse of some kind. On the one hand, Haushofer's protagonist faces the newest product of humankind: a wall most likely originating from a nuclear

11 "The cat stares in the distance with yellow eyes. Sometimes she suddenly comes back to me, and her eyes compel me to stretch out my hand and stoke her round head with the black M on the forehead" (TW: 128). 
weapon (DW: 209). On the other hand, Morton (2013: 99) uses the expression "end of the world" to question the aesthetics underlying the idea of 'world' as a "container in which objectified things float or stand".

Yet as different as 'hyperobject' and the wall may seem, they both express the ancient meaning of apocalypse, the word indicating the ritual digging of a pit in the outskirts of the city in honour of the dead in order to prevent their returning home (De Martino 2002: 194). Similarly, Haushofer's wall serves both as a tribute to the dead, the wall being like a shrine at which to admire a modern Pompeii (DW: 56), and as a denial of death. In analogy, Morton (2013: 103) represents reactions to hyperobjects on a scale that stretches from denial to melancholy.

Secondly, hyperobjects problematize Haushofer's depiction of the wall as something in front of the protagonist. In the epistemological context of Morton's philosophy, most of her struggles not to touch the wall express longing for the avoidance of all intimacy with the Uncanny. For Morton (2013: 33), intimacy means the inevitable proximity of hyperobjects. The loss of a safe distance from troubling events, such as climate change, results in a forced cohabitation with unknown phenomena, causing normality to appear extraneous, unreal. Haushofer's protagonist questions the plausibility of the wall: such things do not occur normally in Austria, nor in Europe (DW: 19).

For the purposes of the present article, Morton's phenomenology has two consequences on the study of landscape as it problematizes the pictorial metaphor pertinent to the term 'landscape' and renegotiates the concept of 'technique'.

In the etymology of 'landscape', perception and depiction have traditionally been intertwined: landscape is both a real, perceptible territory and its metaphorical representation. Those two characteristics are first synonymous and then interrelated: through its imaginary, aesthetics conveys and influences the cultural view of landscape (Milani 2017: 51).

However, the fact that Morton views landscape as a picture hanging from a wall clashes with the spatial and temporal fluctuation of hyperobjects (Morton 2013: 74). If those are to be thought of as landscape, then the latter is to be seen not as a painting but as a snapshot. Thus, it is no surprise that Haushofer has set her novel in the mountains, where the landscape has proved to be more suitable for photography than for painting (Cosgrove, Della Dora 2012: 12).

Thinking of landscape in terms of a hyperobject also means reflecting upon its temporality. Whereas landscape studies mostly deal with changes over long-lasting periods, hyperobjects rather focus on minimal, constant oscillations. If thinking in the latter terms, research on landscape would involve what Donna Haraway (2016: 1) defines as "staying with the trouble": living and thinking being truly present, that is, focussing on little variations of patterns. Similarly, Haushofer's protagonist 
survives, having come to terms with her past and having renounced disclosing of the future.

Landscape shifts out of focus, its spatial and temporal boundaries start to interrelate, to blend in with one another. Rather than being a picture, it is a collection of instantaneous fragments with no discernible progression or timeline: something very similar to Georg Simmel's concept of nature as an incessant flow of phenomena (Simmel 1957: 72). In this respect, hyperobjects put the concept of technique in a new perspective.

\subsection{One plus one equals three: Unmaking the wall}

As Rocco Ronchi (2017: 252) argues, in revisiting the Western view of nature the concept of technique plays a great role. In particular, he speaks in favour of George Simondon's understanding of technique as the formal constituting of human experience (Ronchi 2017: 254). The understanding of technique not as a product, but as a process, permits us to reflect upon the technical history of humankind in terms similar to the naturans of nature (Ronchi 2017: 254). Technique reveals itself as a natural praxis, because the human ability of inventing and using technical prosthesis has roots in nature (Ronchi 2017: 256-257). In a similar way, in her novel Haushofer imagines a process of re-naturalization of technical artefacts: old vehicles abandoned in the woods are a home for wild animals (DW: 78).

More generally, the relevance of technique emerges in the protagonist's longing for dexterity. On the one hand, her complaining about her clumsiness meets the demands of the robinsonade, as she must survive in a hostile environment. On the other hand, dexterity is part of a broader process of renegotiation of epistemology: as Haushofer points out, the new reality is to be experienced with "hands, feet and guts" (TW: 50).

An interesting starting point for reflecting on the post-apocalyptic meaning of technique in the novel is the construction of a boundary. The protagonist attends to the work in two stages, initially contenting herself with driving some branches into the mud near the wall (DW: 20) and then carrying two knives with her to cut them: the jack-knife of Hugo, her cousin's husband, and her own penknife for sharpening pencils (DW: 29). The boundary extends along the wall, making it visible and hence less dangerous, and results in a sort of palisade.

The two knives constituting the equipment express two gestural programmes. Greimas' (1970: 69) concept of 'gestural programme' is part of a broader study on semiotics of the human body in cultures and their gestural praxis: the use of the body relies upon a common project and a shared sense. Greimas' working hypothesis is that phonological methods and practices apply to gestural 
signification because gestures correspond to expression (Greimas 1970: 85) the only difference lies in the fact that a gestural sequence is a "programme of manifestation without a phonological project" (Greimas 1970: 86). Referring to this methodological frame, Haushofer's reference to the two knives expresses the clashing of two gestural programmes of technical intervention on landscape: weaponry and modesty.

The protagonist claims that she carries Hugo's jack-knife because it gives her an apparent sense of protection (DW: 22). Haushofer points out that Hugo's knife, belonging to his arsenal, is one of those objects that should have protected him from the nuclear Armageddon he feared (DW: 10). ${ }^{12}$ Haushofer, who has emphasized Hugo's pointless hoarding of provisions, now marks a disproportion between the sharpness of his knife and the way the protagonist uses it for a very modest purpose. The boundary she makes by cutting branches is a distraction, a springtime game (DW: 20) and speaks more generally for a modest practice of technique, thus implicitly pleading in favour of what Hans Jonas (2000: 122) called 'technical modesty': the fact that something less than perfect could be accepted as good and the consequent dismissal of technical megalomania.

While the wall is described as the consequence of human hubris toward nature, the gestural programme of the making of the boundary creates a harmless replica of the wall, a "toy boundary" (TW: 13). In reference to such a boundary, it is interesting to remind that the word for 'wall' designates also 'a fortification made of branches' in the German language. ${ }^{13}$

\subsection{Troubles in translation}

To clarify how the gestural programmes of technical omnipotence (the wall) and modesty (the palisade) intertwine, a reference to Juri Lotman's semiotics is in order. Lotman (2000: 140) understands boundaries as means and spaces for different semiospheres to transect, thus problematizing Bakhtin's concept of exotopy for the study of landscape.

For Lotman (2000: 140), boundaries mark the outer and the inner parts of semiospheres. The latter define the whole semiotic space of a culture, which is its result and a condition for its development (Lotman 2000: 125). As different semiospheres contain different elements and functions, the transition of a message

\footnotetext{
12 "At the time everyone was talking about nuclear wars and their consequences, and this led Hugo to keep a little store of food and other important things in his hunting-lodge" (TW: 3-4). 13 See https://woerterbuchnetz.de/?sigle=DWB\#4. Indeed, the reference to branches recurs in a further passage of Haushofer's novel indicating the profound alienation of the protagonist from nature: crushing branches under boots is for her another facet of human violence towards the environment (DW: 62).
} 
from one semiosphere into another occurs at the price of adjustments through translations (Lotman 2000: 140). In this respect, Haushofer's first boundary appears to be the wall that filters and adapts the external into the internal, to paraphrase Lotman (2000: 140). In the novel, this dynamic involves a renegotiation of the opposition between the centre and the periphery of the cultural system: after the emergence of the wall, the protagonist realizes that she lives in the farther portion of Western geography, that she names Belutschistan (DW: 49).

Yet the wall also appears as a sign, "something that stands for something, to someone in some capacity" (Ponzio 2003: 122). More precisely, the wall reveals itself as a sign after the making of its interpretant, the palisade. For Peirce, a sign means something in response to another sign (Ponzio 2003: 181), and the construction of the palisade represents a reaction to the wall: having realized it is a weapon (DW: 41), the protagonist replies by defending herself with a palisade, translating the grounding element of the wall into a new boundary.

What changes during this translation is the meaning of order. On the one side, the making of the palisade is a remedy against the violation of the cosmic order caused by the wall (DW: 29). On the other side, the space delimited by the palisade is one of disorder and trouble: a word expressing how "to live and die well with each other in a thick present" (Haraway 2013: 1). Indeed, a thick present is the place beyond the palisade. Due to the staggering increase of wild animals caused by the extinction of humans, there are not enough natural resources for them to survive without the help of the protagonist, as the wall precludes access to a considerably vast portion of the earth. On the protagonist's side of the wall, every action of the protagonist risks damaging an environment already out of balance.

\section{Final observations: Towards a post-apocalyptical understanding of the face}

\subsection{Wood walks with her}

When reflecting on the intertwining of intentions, directions and species during the Anthropocene, Haraway (2013: 58) coins the concept of 'sympoesis'. The neologism emphasizes the creative interdependence of earthlings, thus referring to a responsive, collective making of the word - a "wordling-with, in company" (Haraway 2013: 58). Systems so defined defy spatial and temporal boundaries: while the latter are usually "centrally controlled", sympoetic systems distribute information and control among their components (Haraway 2013: 61). Haushofer's protagonist experiences something similar to sympoesis in the final pages of the novel: "Manchmal verwirren sich meine Gedanken und es ist, als fange der Wald an, 
in mir Wurzeln zu schlagen und mit meinem Hirn seine alten, ewigen Gedanken zu denken. [...] Es fällt mir schwer, beim Schreiben mein früheres und mein neues Ich auseinanderzuhalten" (DW: 185). ${ }^{14}$

Referring to her protagonist's trouble in distinguishing between what she was and what she is while writing, Haushofer problematizes the act of writing as a means of understanding reality: while the report gives the protagonist's thoughts formal coherence, it forces her to become aware of her dissolving identity. Here, 'dissolving' is used in the meaning of what Roberto Marchesini (2002: 189) defines as somato-landscape: the transferring of landscape inside the human body. In Haushofer, somato-landscape arises because writing urges both the psychological and physical awakening of the Self and the epistemological revision of the experience of the landscape. This provides the protagonist with tools for the recollection, and thus the recognition, of herself.

Meschiari (2008: 60) has convincingly compared writing with mapping. The similarity of these processes lies above all in the fact that both deal with unstable objects: fiction with narrative plausibility and maps with the making and unmaking of territories. The similarity between writing and mapping seems particularly true for Haushofer's novel, where the branches for the palisade were cut with a knife meant for sharpening pencils (DW: 29).

The protagonist's interrelation with the wood adds a puzzling question to the depiction of mobility and immobility in the landscape. Whereas to some extent the wall and the palisade stand for a reflection upon obstructed mobility, the woods introduce a new variable in the reflection upon the landscape: that of "smooth" space.

\subsection{Face and other lines}

In the second volume of their study A Thousand Plateaus: Capitalism and Schizophrenia, Gilles Deleuze and Félix Guattari thematize distinctions and interrelations between a "striated" and a "smooth" perception of space and understanding these in different cultural models.

Roughly distinguished, these perceptions correspond to the sedentary and the nomadic experiences of places, respectively. In striated spaces, one goes from one point to another, whereas in smooth spaces, points are less important than trajectories: the movement in the landscape contemplates the possibility of changes of direction (Deleuze, Guattari 1980: 596). The experience of smooth spaces has

\footnotetext{
14 "Sometimes my thoughts grow confused, and it is as if the forest has put down roots in me, and is thinking its old, eternal thoughts with my brain [...]. I find it hard to separate my old self from my new self" (TW: 161).
} 
no visual points of reference or invariant distances. Differently from the striated space, smooth space is made up of a steady changing orientation provided by a population of nomads who are actively entertaining tactile relations among themselves (Deleuze, Guattari 1980: 598).

In Haushofer's novel, it appears clear how the wall orientates the landscape towards a smooth model of space by forcing the protagonist towards a mostly tactile perception of space. For the first time, the protagonist realizes that something invisible is blocking her path by bumping into it: then, she carefully approaches the wall with outstretched hands. Although she tries to avoid contact with the wall, its invisibility forces her to trust her tactile perception instead of her eyes.

The analogy with Deleuze and Guattari's theoretical frame becomes even more striking at the end of the novel. Observing how a mountain brook has succeeded in leaking into the wall, the protagonist is relieved: "Mit dem Wasser aus den Bächen wird das Leben, winziges, einfaches Leben, einsickern und die Erde wiederbeleben" (DW: 223). ${ }^{15}$ With the wish for the renewal of life in an elementary form, she implicitly expresses the longing for the smooth space par excellence. That is water (Deleuze, Guattari 1980: 597). Furthermore, the smooth experience of the landscape clarifies the protagonist's symbolic metamorphosis into a tree, as before noticing how her thoughts seems to have their roots in the woods rather than being her own, the protagonist gives a final depiction of herself: "Ich bin noch immer mager, aber muskulös, und mein Gesicht ist von winzigen Fältchen durchzogen. Ich bin nicht häßlich, aber auch nicht reizvoll, einem Baum ähnlicher als einem Menschen" (DW: 182). ${ }^{16}$

The process of metaphorically becoming part of the woods can be interpreted as an allegorical longing for smooth space. As Deleuze and Guattari (1980:602) praise the attachment to a territory explored through the mind as the ultimate nomadic experience of modern times, Haushofer imagines that her protagonist metaphorically travels into the woods without actually moving (DW: 185). Yet the similarity the protagonist feels to have acquired with trees goes somehow in the same direction as Deleuze's and Guattari's critique of Western emphasis on the face as a means of fixing identity into one space (Deleuze, Guattari 1980: 623). Undulations, frictions, variations: the smooth space dissolves the face into a riddle of intersecting lines and spirals. What Haushofer describes as wrinkles are trajectories, points and lines of a new face in landscape. ${ }^{17}$

15 "With water from the streams life, tiny, simple life, will seep in and revivify the earth" (TW; 196).

16 "I am still scrawny, but muscular, and my face is criss-crossed with tiny wrinkles. I'm not ugly, but neither am I attractive, more like a tree than a person" (TW: 69).

17 I dedicate this paper to my brother. 


\section{References}

Assunto, Rosario 2005[1973]. Il paesaggio e l'estetica. Palermo: Novecento.

Battiston, Régine 2019. Funktion der Landschaft in Marlen Haushofers Werk. In: Alraud, Sylvie; Lacheny, Marc; Lajarraige, Jacques; Leroy du Cardonnoy, Éric (eds.), Dekonstruktion der symbolischen Ordnung bei Marlen Haushofer. Berlin: Frank \& Timme, 39-57.

Baczko, Bronisław 1978. L'utopia. Immaginazione sociale e rappresentazioni utopiche nell'età dell'Illuminismo. (Botto, Margherita; Gibelli Dario, trans.) Torino: Einaudi.

Berque, Augustin 1994. Cinq propositions pour une théorie du paysage. Ceyzérieu: Champ Vallon.

Chamayou-Kuhn, Cécile 2019. Grenz und Fremdheitserfahrungen in „Die Wand“. In: Alraud, Sylvie; Lacheny, Marc; Lajarraige, Jacques; Leroy du Cardonnoy, Éric (eds.), Dekonstruktion der symbolischen Ordnung bei Marlen Haushofer. Berlin: Frank \& Timme, 17-39.

Chlovanec, Johanna 2016. Marlen Haushofers „Die Wand“ als Thirdspace. Sprachkunst Beiträge zur Literaturwissenschaft 1: 15-30. https://doi.org/10.1553/spk45_1s15

Collot, Michel 2015. Landschaft. In: Dünne, Jörg; Mahler, Andreas (eds.), Handbuch Literatur \& Raum. Berlin: De Gruyter, 151-159.

Cosgrove, Denis; Della Dora, Veronica 2012. Introduction: High places. In: Cosgrove, Denis; Della Dora, Veronica (eds.), High Places: Cultural Geographies of Mountains, Ice and Science. London: Palgrave Macmillan, 1-18.

D’Angelo, Paolo 2001. Estetica della natura: bellezza naturale, paesaggio, arte ambientale. Bari: Laterza.

D’Angelo, Paolo; Catucci, Stefano; Carchia, Gianni 1999. Dizionario di estetica. Bari: Laterza.

Deleuze, Gilles; Guattari, Félix 1980. Mille Plateaux. Paris: Edition du Minuit.

De Martino, Ernesto 2002. La fine del mondo. Contributo all'analisi delle apocalissi culturali. Torino: Einaudi.

Eco, Umberto 1985. Sugli specchi e altri saggi. Milano: Bompiani.

Greimas, Algirdas Julien 1970. Del senso. Milano: Bompiani.

Haraway, Donna J. 2016. Staying with the Trouble. Durham, London: Duke University Press. https://doi.org/10.2307/j.ctv11cw25q

Haushofer, Marlene. 1985. Die Wand. Berlin: Ullstein Taschenbuch Verlag.

Haushofer, Marlene. 1999. The Wall. (Whiteside, Shaun, trans.) Berkeley: Cleis Press.

Hoffmann, Michael 2000. Verweigerte Idylle. Weiblichkeitskonzepte im Widerstreit zwischen Robinsonade und Utopie: Marlen Haushofers Roman „Die Wand“. In: Bosse, Anke; Ruthner, Clemens (eds.), „Eine geheime Schrift aus diesem Splitterwerk enträtseln... "Marlen Haushofers Werk im Kontext. Tübingen: Franke Verlag, 193-207. Jakob, Michael 2005. Paesaggio e letteratura. Firenze: Olschki.

Jonas, Hans 1993. Il principio responsabilità. Torino: Einaudi.

Kalinova, Maria 2018. Exotopy: Mikhail Bakhtin and Jacques Lacan on the outside context of discourse. Slavica Tergestina 1: 98-117.

Knecht, Maria-Regina 2007. Recollections of crime and complicity. Studies in 20th \& 21st Century Literature 31: 82-108. https://doi.org/10.4148/2334-4415.1645 
Lehmann, Annette Jael 2021. Environments: Künste - Medien - Umwelt: Facetten der künstlerischen Auseinandersetzung mit Landschaft und Natur. Bielefeld: Transcript.

Leone, Massimo 2015. Signatim. Profili di semiotica del testo. Roma: Aracne.

Lévinas, Emmanuel 1977[1961]. Totalità e infinito. Milano: Jaka Book.

Lotman, Yuri 2000. Universe of the Mind: A Semiotic Theory of Culture. (Shukman, Ann, trans.) Bloomington: Indiana University Press.

Marchesini, Roberto 2002. Post-human: verso nuovi modelli di esistenza. Torino: Bollati Boringhieri.

Meschiari, Matteo 2008. Sistemi selvaggi. Antropologia del paesaggio scritto. Palermo: Sellerio.

Milani, Raffaele 2017. L'arte del paesaggio. Bologna: Il mulino.

Morton, Timothy 2011. Zero landscapes in the time of hyperobjects. Graz Architectural Magazine 2011, 78-87.

Morton, Timothy 2013. Hyperobjects. Minneapolis: University of Minnesota Press.

Nelseen, Sarah 2019. Zwei weibliche Robinsonaden? Eine vergleichende Lektüre von Marlen Haushofers „Die Wand“ und „Die Mansarde“. In: Alraud, Sylvie; Lacheny, Marc; Lajarraige, Jacques; Leroy du Cardonnoy, Éric (eds.), Dekonstruktion der symbolischen Ordnung bei Marlen Haushofer. Berlin: Frank \& Timme, 127-143.

Ponzio, Augusto 2003. Tra semiotica e letteratura. Milano: Jaka Books.

Predoiu, Graziella 2016. Raumkonstellationen in Marlen Haushofers Roman „Die Wand“. Germanistische Beiträge 36: 66-88.

Ricoeur, Paul 2004. Percorsi del riconoscimento. Milano: Raffaele Cortina Editore.

Ronchi, Rocco 2017. Il canone minore: verso una filosofia della natura. Milano: Feltrinelli. Schama, Simon 1995. Landscape and Memory. New York: Alfred A. Knopf.

Simmel, Georg 2009[1985]. Philosophie der Landschaft. Stühlingen an der Wutach: Mahler Verlag.

Sobral Campos, Isabel 2019. Ecopoetics and the Global Landscape: Critical Essays. Lanham, London: Lexington Books.

Stephan, Inge; Weigel, Sigrid 1988. Die Verborgene Frau. Sechs Beiträge zu einer feministischen Literaturwissenschaft. Berlin: Literatur Verlag.

Starobinski, Jean 1957. Locchio vivente. Torino: Einaudi.

Venske, Regula 1987. "Vielleicht, daß ein sehr entferntes Auge eine geheime Schrift aus diesem Splitterwerk enträtseln könnte...”. Zur Kritik der Rezeption Marlen Haushofers. In: Duden, Anna (ed.), „Oder war da manchmal noch etwas anderes?“ Texte zu Marlen Haushofer. Frankfurt: Verlag Neue Kritik, 43-67.

Venske, Regula 1991. "Schriftstellerin mit der Seele eines Möbelpackers": Marlen Haushofer. In: Das Schreiben der Frauen in Österreich seit 1950. Wien: Böhlau Verlag, 22-32.

Vitta, Maurizio 2005. Il paesaggio. Una storia tra natura e architettura. Torino: Einaudi.

Von der Lühe, Irmela 1986. Erzählte Räume - leere Welt. Zu den Romanen Marlen Haushofers. In: Duden, Anna (ed.), „Oder war da manchmal noch etwas anderes?" Texte zu Marlen Haushofer. Frankfurt: Verlag Neue Kritik, 73-103.

Weber, Kurt H. 2010. Die literarische Landschaft. Berlin, New York: De Gruyter. https:// doi.org/10.1515/9783110227642

Zeyringer, Klaus 2001. Österreichische Literatur seit 1945. Überblicke. Einschnitte. Wegmarken. Innsbruck: Haymon Verlag. 


\section{«Стена» Марлена Хаусхофера и пост-ядерная культура лица}

Переплетение ландшафта и лица принадлежит к пространственной эпистемологии человека: как предположил Маттео Мескьяри, примитивные люди привыкли ориентироваться в пространстве, распознавая образы лица. Размышляя над романом Марлена Хаусхофера «Стена», мы ставим под вопрос значение «лица пейзажа» после воображаемого ядерного апокалипсиса, оставившего после себя лишь кошку, корову, собаку, женщину и стену. Стена размывает границу между человеческим и тем, что не является человеком. С точки зрения Роберто Маркесини, она создает телесный ландшафт - гибрид внутренних и внешних ландшафтов, типичный для постчеловеческого сознания. Наконец, кульминацией такого пейзажа становится отказ от существовавшей до апокалипсиса культуры лица, когда лица уже не являются средствами распознавания.

\section{Marlen Haushoferi “Üksinda maailmas" ("Die Wand") ja tuumakatastroofijärgne näokultuur}

Maastiku ning näo teineteisesse põimumine kuulub inimliku ruumiepistemoloogia juurde: nagu on osutanud Matteo Meschiari, leidsid primitiivsed inimesed maastikul orientiire näomustreid ära tundes. Artiklis mõtiskletakse Marlen Haushoferi romaani "Üksinda maailmas" üle ning esitatakse küsimusi "maastiku näo" semantika kohta pärast kujuteldavat tuumakatastroofi, millest jäävad järele kass, lehm, koer, naine ja müür. Müür ületab inimese ja muu-kui-inimese vahelise piiri: Roberto Marchesini mõisteid kasutades loob see kehamaastiku - posthumaansele teadvusele omase sise- ja välismaastiku hübridiseerumise. Selline maastik kulmineerub lõpuks apokalüpsise-eelsest näokultuurist loobumisega: näod ei toimi enam äratundmisvahendina. 